\title{
PENGARUH PENGEMBANGAN KARIER, KOMITMEN ORGANISASIONAL DAN PERCEIVED ORGANIZATIONAL SUPPORT TERHADAP RETENSI KARYAWAN
}

\author{
Ni Komang Astri Pramita Darmika ${ }^{1}$ \\ Anak Agung Ayu Sriathi \\ ${ }^{1,2}$ Fakultas Ekonomi dan Bisnis Universitas Udayana (Unud), Bali, Indonesia \\ E-mail: astridarmika@gmail.com
}

\begin{abstract}
ABSTRAK
Penelitian ini bertujuan untuk mengetahui pengaruh pengembangan karier, komitmen organisasional dan perceived organizational support terhadap retensi karyawan. Penelitian ini dilakukan di The Lokha Ubud. Jumlah sampel yang digunakan yaitu sebanyak 85 orang karyawan, dengan metode sampel jenuh dimana semua jumlah populasi dijadikan sampel. Pengumpulan data diperoleh dari observasi, wawancara dan penyebaran kuesioner. Teknik analisis yang digunakan adalah analisis regresi linear berganda. Hasil penelitian ini menemukan bahwa pengembangan karier berpengaruh positif dan signifikan terhadap retensi karyawan, komitmen organisasional berpengaruh positif dan signifikan terhadap retensi karyawan dan perceived organizational support berpengaruh positif dan signifikan terhadap retensi karyawan. Dalam meningkatkan retensi karyawan maka perusahaan diharapkan perlu memperhatikan hubungan karyawan dengan atasan dalam kaitannya dengan pengembangan karier serta karyawan mendapatkan informasi yang lengkap mengenai syarat dalam menduduki suatu jabatan.
\end{abstract}

Kata kunci: pengembangan karier, komitmen organisasional, perceived organizational support, retensi karyawan

\begin{abstract}
This study aims to determine the effect of career development, organizational commitment and perceived organizational support for employee retention. This research was conducted at The Lokha Ubud. The number of samples used is as many as 85 employees, with a saturated sample method where all population numbers are sampled. Data collection was obtained from observation, interviews and questionnaires. The analysis technique used is multiple linear regression analysis. The results of this study found that career development has a positive and significant effect on employee retention, organizational commitment has a positive and significant effect on employee retention and perceived organizational support has a positive and significant effect on employee retention. In increasing employee retention, the company is expected to need to pay attention to employee relations with superiors in relation to career development and employees get complete information about the conditions in occupying a position

Keywords: career development, organizational commitment, perceived organizational support, employee retention
\end{abstract}


Ni Komang Astri Pramita Darmika, Pengaruh Pengembangan Karier...

\section{PENDAHULUAN}

Pulau Bali merupakan salah satu destinasi wisata yang ada di Indonesia. Bali yang memiliki keragaman adat budaya dan panorama alam yang sangat indah menjadi ciri khas dan daya tarik wisata. Dengan segala keunikan yang dimiliki, mampu menarik wisatawan dari mancanegara maupun lokal untuk berkunjung ke Pulau Bali. Bisnis pariwisata yang ada di Bali sangatlah menjanjikan, sehingga banyak berdiri perusahaan yang bergerak di bidang pelayanan jasa. Salah satu pelayanan jasa yang dimiliki Bali adalah hotel-hotel yang berfungsi sebagai sarana akomodasi tempat menginap para wisatawan mancanegara maupun lokal.

Sektor pariwisata di Bali yang semakin berkembang harus dikelola secara baik dengan sumber daya manusia yang berkualitas. Sumber daya manusia merupakan assets yang sangat penting. Tanpa adanya sumber daya manusia maka perusahaan tidak akan berjalan, tidak akan berproduksi, dan tidak akan mencapai tujuan yang telah ditetapkan. Begitu pula pada perusahaan pelayanan jasa yang ada di Bali, tenaga kerja atau sumber daya manusia dapat mempengaruhi perkembangan hotel dan ikut berperan dalam menjalankan aktivitas hotel (Mustika, 2012). Sumber daya manusia harus dikelola dengan baik, jika perusahaan tidak dapat mengelola sumber daya manusia dengan baik maka akan berdampak pada tingginya keinginan untuk keluar dari karyawan. Untuk menanggulangi hal tersebut perusahaan harus mampu mempertahankan karyawannya agar perusahaan dapat berjalan dengan baik dan mencapai sasaran yang telah ditetapkan.

Retensi karyawan adalah suatu cara yang dipakai oleh manajemen untuk mempertahankan karyawan yang kompeten agar tetap bertahan dalam perusahaan 
dengan jangka waktu tertentu (Jennifer, 2005:2). (Oladapo, 2014) jika seorang karyawan tidak dapat menggunakan potensinya dengan penuh dan juga tidak dihargai atau didengar di dalam tempat mereka bekerja, maka mereka akan keluar karena stress dan frustasi. Permasalahan yang terjadi di The Lokha Ubud adalah rendahnya retensi karyawan. Hasil wawancara dengan HRD The Lokha Ubud, diperoleh informasi data mengenai perputaran karyawan pada tahun 2015-2017. Berikut adalah data retensi karyawan The Lokha Ubud yang ditunjukkan pada Tabel 1.

Tabel 1.

Data Retensi Karyawan The Lokha Ubud Tahun 2015-2017

\begin{tabular}{cccccc}
\hline \multirow{2}{*}{ Tahun } & $\begin{array}{l}\text { Jumlah } \\
\text { Karyawan }\end{array}$ & $\begin{array}{l}\text { Jumlah } \\
\text { Karyawan } \\
\text { Masuk }\end{array}$ & $\begin{array}{l}\text { Karyawan } \\
\text { Masuk (\%) }\end{array}$ & $\begin{array}{l}\text { Jumlah } \\
\text { Karyawan } \\
\text { Keluar }\end{array}$ & $\begin{array}{l}\text { Karyawan } \\
\text { Keluar (\%) }\end{array}$ \\
\hline 2015 & 102 & 23 & 22,55 & 19 & 18,62 \\
2016 & 99 & 24 & 24,24 & 29 & 29,29 \\
2017 & 93 & 16 & 17,2 & 23 & 24,73 \\
\hline Sumber: HRD The Lokha Ubud, 2017 & & &
\end{tabular}

Menurut data yang diperoleh melalui wawancara dengan HRD The Lokha Ubud rata-rata yang mengundurkan diri sebesar 24,21 persen. Turnover karyawan yang mencapai 5-10 persen tergolong normal apabila lebih dari 10 persen per tahun ini tergolong tinggi (Gillies, 1989). Sehingga rata-rata karyawan yang mengundurkan diri di The Lokha Ubud tergolong sangat tinggi. Pra riset yang dilakukan pada 10 orang karyawan The Lokha Ubud, 80 persen mengatakan bahwa hal yang menyebabkan karyawan banyak yang mengundurkan diri karena karyawan merasa kurangnya pengembangan karier yang baik di dalam perusahaan sehingga karyawan keluar dari perusahaan untuk mencari karier yang lebih baik, sehingga perusahaan rendah dalam mempertahankan karyawan. Mempertahankan karyawan merupakan tujuan penting dari setiap organisasi dan kunci kesehatan jangka 
Ni Komang Astri Pramita Darmika, Pengaruh Pengembangan Karier...

panjang serta keberhasilan suatu organisasi tergantung pada retensi karyawan (Das dan Baruah, 2013). Putra dan Agoes (2016) memelihara tingginya retensi karyawan akan meningkatkan efektifitas dan kinerja perusahaan karena dengan tingginya retensi, maka tentu saja turnover menjadi rendah.

Menurut Mathis and Jackson (2011:128) retensi karyawan dipengaruhi oleh faktor pengembangan karier secara siginifikan. Parerung (2014) menyatakan bahwa pengembangan karier merupakan proses mengidentifikasikan potensi karier pegawai, serta materi untuk menerapkan cara-cara yang tepat dalam mengembangkan potensi tersebut. Pratiwi dan Sriathi (2017) pengembangan karier memberikan kesempatan untuk promosi jabatan dalam suatu organisasi dan memberikan kesempatan untuk pelatihan dan pengembangan keterampilan yang memungkinkan karyawan untuk meningkatkan kerja mereka. Hasil penelitian yang dilakukan oleh Sitati et al. (2016) menyatakan bahwa pengembangan karier berpengaruh positif dan signifikan terhadap retensi karyawan Putra dan Mudiartha (2018) komitmen organisasional menjadi faktor yang mempengaruhi retensi karyawan. Menurut Lamba dan Choudary (2013) komitmen organisasional merupakan sikap loyal yang membuat karyawan untuk tetap bekerja dalam suatu organisasi. Komitmen diartikan sebagai sikap karyawan untuk tetap berada dalam organisasi dan terlibat dalam upaya-upaya mencapai misi, nilai-nilai dan tujuan perusahaan (Syarafuddin, 2008:56). Hasil penelitian yang dilakukan oleh Permata dan Edy (2016) yang mengemukakan bahwa komitmen organisasional berpengaruh positif dan signifikan terhadap retensi karyawan. 
Putra dan Agoes (2016) Perceived organizational support juga mempengaruhi tingkat retensi karyawan. Menurut Wu Wann (2011), bahwa perceived organizational support mengacu pada persepsi karyawan atau penilaian tentang berapa banyak organisasi menghargai kontribusi mereka dan peduli tentang mereka. Tingginya tingkat perceived organizational support di dalam perusahaan yang mengarah kepada tingginya kepuasan kerja dan menurunkan tingkat turnover (Robbins dan Coulter, 2009: 143). Menurut (Wijayanti dan Harlina, 2015) retensi karyawan dapat berhasil karena adanya POS yang positif pada karyawan terhadap apa yang diberikan oleh organisasi sebagai penghargaan atas kontribusi yang diberikan para karyawan terhadap organisasi, POS turut mempengaruhi keberhasilan retensi karyawan pada organisasi dan pada penelitian tersebut didapatkan hasil bahwa perceived organizational support (POS) berpengaruh positif dan signifikan terhadap retensi karyawan.

Menurut Mathis and Jackson (2011:126), retensi adalah upaya perusahaan untuk mempertahankan karyawan agar tetap berada dalam organisasi guna mencapai tujuan organisasi tersebut dalam jangka waktu tertentu. Retensi karyawan merupakan kemampuan yang dilakukan oleh perusahaan untuk mempertahankan karyawan yang memiliki potensi agar tetap loyal dengan perusahaan (Sumarni, 2011). Lebih lanjut menurut Hafanti dkk. (2015) bahwa retensi karyawan adalah kemampuan perusahaan untuk mempertahankan pekerja-pekerja terbaik untuk terus berada dalam organisasi. Menurut Ragupathi (2013), retensi karyawan mengacu pada teknik yang digunakan oleh manajemen untuk membantu karyawan tetap dengan organisasi untuk jangka waktu yang lama. Retensi karyawan juga 
Ni Komang Astri Pramita Darmika, Pengaruh Pengembangan Karier...

merupakan keinginan karyawan untuk bertahan pada perusahaan dalam jangka waktu yang lama. Karyawan harus diperhatikan dan dipelihara dengan sungguhsungguh oleh manajer, jika tidak maka semangat kerja, loyalitas, sikap dan disiplin karyawan akan menurun. Namun tidak semua karyawan akan keluar dari perusahaan, setidaknya masih banyak karyawan yang tetap bertahan bekerja pada perusahaan.

Samuel dan Chipunza (2009) menyatakan tujuan utama dari retensi adalah mencegah keluarnya karyawan yang memiliki keahlian dari organisasi, karena dapat memiliki efek buruk pada produktivitas organisasi. Dari pengertianpengertian yang telah dikemukakan, bahwa retensi karyawan adalah suatu proses dimana sebuah perusahaan mampu mempertahankan karyawannya yang potensial agar tetap loyal terhadap perusahaan dengan jangka waktu yang lebih lama.

Wahyuni (2014) pengembangan karier merupakan proses peningkatan kemampuan kerja individu yang terlihat mulai dalam kegiatan perencanaan dan pencapaian sasaran. Menurut Haryani (2013) pengembangan karier yakni menyangkut proses pengindentifikasi kemampuan karier karyawan dan melalui penerapan model yang tepat untuk mendapatkannya. Pengembangan karier merupakan serangkaian aktivitas sepanjang hidup (seperti workshop) yang berkontribusi pada eksplorasi, pemantapan, keberhasilan dan pencapaian karier seseorang (Dessler, 2009: 5).

Pengembangan karier adalah proses peningkatan kemampuan kerja individu yang dicapai dalam rangka mewujudkan karier yang diinginkan (Candra, 2016). Pengembangan karier merupakan aspek penting yang tidak boleh dilupakan dalam 
mengelola sumber daya manusia (Sari dan Sinulingga, 2011). Dari beberapa pengertian tersebut dapat dikemukakan bahwa pengembangan karier adalah suatu proses peningkatan kerja karyawan yang terlihat dari jenjang karier yang bisa didapatkan oleh karyawan.

Griffin (2004 : 15) menyatakan komitmen organisasional merupakan sikap yang menggambarkan seorang karyawan terikat pada organisasi. Menurut Luthans (2008:147) komitmen organisasional adalah keinginan yang kuat yang dimiliki seseorang untuk mempertahankan keanggotaan dalam organisasi. Robbins dan Judge (2015) menyatakan komitmen organisasional merupakan suatu keadaan yang membuat karyawan memihak terhadap tujuan organisasi dan memiliki keinginan untuk mempertahankan keanggotaannya. Menurut Malik et al. (2013) komitmen organisasi akan meningkat jika karyawan merasa memiliki hak untuk terlibat atau ikut serta dalam pengambilan keputusan dan merasa tujuannya sesuai dengan tujuan organisasi. Crow et al. (2012) menyatakan bahwa komitmen organisasional merupakan keadaan psikologis seorang pegawai yang dapat dilihat dari rasa loyalitas pegawai serta mampu fokus terhadap tujuan yang telah ditetapkan oleh organisasi. Dari beberapa pengertian tersebut dapat dikemukakan bahwa komitmen organisasional adalah rasa memiliki yang tinggi terhadap organisasi sehingga karyawan memiliki kecenderungan untuk tetap berada di dalam organisasi.

Perceived organizational support (POS) atau persepsi dukungan organisasi merupakan persepsi karyawan terhadap organisasi mengenai sejauh mana organisasi menghargai kontribusi dan peduli tentang kesejahteraan mereka (Rhoades dan Eisenberger, 2002:698). Menurut Grace (2013), bahwa perceived 
Ni Komang Astri Pramita Darmika, Pengaruh Pengembangan Karier...

organizational support didefinisikan sebagai kepercayaan karyawan bahwa organisasi menghargai kontribusi dan kesejahteraan mereka. Sebuah perusahaan apabila ingin mempertahankan dan meningkatkan retensi karyawannya, maka perusahaan nantinya perlu meningkatkan perceived organizational support (Cahyana, 2013). Teori dukungan organisasi beranggapan bahwa untuk organisasi memberikan rewards atas peningkatan kinerja dan memenuhi kebutuhan sosioemosional, karyawan terhadap organisasi, mengembangkan kepercayaan bahwa organisasi menghargai kontribusi dan memperhatikan kesejahteraan mereka. Dukungan organisasi yang dirasakan berasal dari salah satu teori tradisional terkait dengan hubungan antara pengusaha dan karyawan berdasarkan harapan dan kewajiban bersama (Farasat, 2013).

Menurut Wu Wann (2011), bahwa perceived organizational support mengacu pada persepsi karyawan atau penilaian tentang berapa banyak organisasi menghargai kontribusi mereka dan peduli tentang mereka. Karyawan melihat pekerjaan mereka sebagai hubungan pertukaran timbal balik yang mencerminkan relatif ketergantungan dan melampaui kontrak resmi. Karyawan perlu menentukan apakah, dan sejauh mana, organisasi akan memperhatikan dan menghargai usaha mereka, mendukung kebutuhan sosio-emosional mereka, dan membantu mereka atas permintaan. Menurut Benlioglu (2014), persepsi dukungan organisasi dibuat dengan alasan kondisi pekerjaan dan beberapa praktek sumber daya manusia memberikan penciptaan sikap positif karyawan dan perilaku. Perlakuan yang adil, dukungan pengawasan, dan penghargaan dan kondisi kerja yang menguntungkan menunjukkan hubungan yang kuat dengan dukungan organisasi yang dirasakan. 
Menurut Robbins dan Coulter (2009:143) menyatakan tingginya tingkat perceived organizational support di dalam perusahaan yang mengarah kepada tingginya kepuasan kerja dan menurunkan tingkat turnover. Dari pernyataan tersebut, perceived organizational support adalah seberapa besar dukungan organisasi yang dirasakan karyawan terhadap kontribusi mereka dan kepedulian organisasi terhadap kesejahteraan mereka yang akan berdampak kepada dukungan karyawan terhadap organisasi.

Menurut Farasat (2013), menyatakan bahwa terdapat 4 dimensi yang dapat meningkatkan dukungan organisasi yang dirasakan karyawan, yaitu: 1) Keadilan (Fairness). Prosedur yang adil dapat digunakan sebagai indikator bagi orang-orang sehingga mereka (karyawan) merasa dihargai dan dihormati dalam organisasi. 2) Dukungan atasan (Supervisor). Dukungan atasan telah didefinisikan sebagai sejauh mana manajer berkomunikasi dengan bawahan mereka dan membantu dan mendukung mereka. Dukungan atasan dapat memperkuat dukungan organisasi yang dirasakan dengan menciptakan kepercayaan dan keyakinan dalam organisasi, 3) Imbalan organisasi (Organizational rewards). Berdasarkan teori dukungan organisasi yang dirasakan, karyawan mengembangkan kepercayaan umum mereka sejauh bahwa mereka merasa bahwa organisasi siap untuk menghargai usaha mereka, untuk memenuhi kebutuhan sosial dan emosional mereka, dan merawat mereka partisipasi dan kesejahteraan. 4) Kondisi kerja (Conditions). Salah satu bentuk dukungan organisasi pada karyawan adanya kondisi kerja yang nyaman dan aman bagi karyawan. 
Ni Komang Astri Pramita Darmika, Pengaruh Pengembangan Karier...

Teori Harapan adalah kekuatan dari suatu kecenderungan untuk bertindak dalam cara tertentu bergantung pada kekuatan dari suatu harapan bahwa tindakan tersebut akan diikuti dengan hasil yang ada. Teori ini akan digunakan untuk menjelaskan model dalam pendekatan ini. Teori harapan atau Teori Ekspektansi (Expectancy Theory of motivation) dikemukakan oleh Vroom (1964:64), menekankan pada faktor hasil (outcomes), ada tiga asumsi dari teorinya adalah sebagai berikut: setiap individu percaya bahwa bila mereka berperilaku dengan cara tertentu, maka individu tersebut akan memperoleh hal tertentu. Ini disebut sebuah harapan hasil (outcome expentancy) sebagai penilaian subjektif seseorang atas kemungkinan bahwa suatu hasil tertentu akan muncul dari tindakan orang tersebut. Setiap hasil mempunyai nilai, atau daya tarik bagi orang tertentu. Ini disebut valensi (valence) sebagai nilai yang orang berikan kepada suatu hasil yang diharapkan. Teori ini menyatakan bahwa kekuatan yang memotivasi seseorang untuk bekerja giat dalam mengerjakan pekerjaannya tergantung dari hubungan timbal balik antara apa yang diinginkan dan dibutuhkan dari hasil pekerjaan itu.

Teori harapan yang digunakan dalam penelitian ini karena di dalam teori harapan ini dijelaskan bahwa terdapat harapan dari hasil suatu pekerjaan karyawan yang memotivasi seseorang lebih giat dalam melakukan pekerjaan. Harapan di dalam penelitian ini berhubungan dengan dukungan organisasi yang didapat karyawan setelah melakukan pekerjaan. Teori harapan menjelaskan adanya pengaruh dukungan organisasi secara signifikan terhadap retensi karyawan. Perusahaan diharapkan mampu memberikan rewards atas peningkatan pekerjaan dan memenuhi kebutuhan sosio-emosional karyawan dan mengembangkan 
kepercayaan bahwa perusahaan memperhatikan kesejahteraan karyawan. Dengan terbentuknya kepercayaan karyawan terhadap perusahaan maka karyawan akan bertahan di dalam perusahaan. Artinya perusahaan mampu mempertahankan karyawan.

Aditeresna dan Mujiati (2018) pengembangan karier dapat mempengaruhi retensi ketika karyawan mendapatkan perlakuan adil dalam berkarier, atasan selalu mendukung karyawan untuk mengembangkan kariernya dan memiliki latar belakang pendidikan formal yang cukup untuk menunjang kariernya. Hal ini didukung dengan beberapa penelitian yang dilakukan oleh Pratiwi dan Sriathi (2017) menyatakan bahwa pengembangan karier berpengaruh positif dan signifikan terhadap retensi karyawan pada Hotel Santika Nusa Dua Bali. Kwenin (2013) menemukan bahwa pengembangan karier secara positif dan signifikan mempengaruhi retensi karyawan di Vodafone Ghana Limited. Penelitian dilakukan Kroon and Freese (2013) menemukan bahwa peluang pengembangan karier dapat secara positif meningkatkan komitmen karyawan untuk tinggal di organisasi.

Poerbaningtyas (2015) melakukan pnelitian yang menunjukan bahwa pengembangan karier mempengaruhi retensi karyawan, dimana artinya jika pengembangan karier meningkat maka retensi karyawan akan meningkat pula. Hasil penelitian Ramadhani dan Engkos (2013) juga menunjukan bahwa bahwa pengembangan karier memberikan pengaruh yang positif dan signifikan terhadap retensi karyawan. Khan (2014) menemukan bahwa pengembangan karier meningkatkan retensi karyawan terhadap perusahaan. 
Ni Komang Astri Pramita Darmika, Pengaruh Pengembangan Karier...

Berdasarkan studi empiris sebelumnya, hipotesis yang dapat diajukan dalam penelitian ini adalah sebagai berikut.

$\mathrm{H}_{1}$ : Pengembangan karier berpengaruh positif dan signifikan terhadap retensi karyawan.

Perusahaan perlu memiliki komitmen organisasional, karena untuk mempertahankan karyawan komitmen organisasional merupakan faktor penting di dalam mencapai tujuan organisasi (Fahrizal dan Mudiartha, 2017). Karyawan yang loyal akan bersedia untuk memprioritaskan kepentingan perusahaan daripada kepentingan pribadi mereka (Robbins and Judge, 2015). Adanya beberapa penelitian mengenai hubungan antara komitmen organisasi dan retensi karyawan yakni, penelitian dari Nguyen (2014) didapatkan bahwa komitmen organisasi berpengaruh positif dan signifikan terhadap retensi karyawan. Fukuoka (2014) dimana hasil dari variabel komitmen organisasional mempunyai hubungan yang positif terhadap retensi karyawan. Rose and Raja (2016) menemukan bahwa komitmen organisasional berpengaruh secara positif dan signifikan terhadap retensi karyawan.

Penelitian juga dilakukan oleh Ula dan Wahibur (2016) menyatakan bahwa komitmen organisasional berpengaruh positif dan signifikan terhadap retensi di PT. Selok Jaya di Kecamatan Juwana Penelitian dari Shanker (2013) menunjukkan bahwa dua dari jenis komitmen organisasional, yaitu komitmen afektif dan komitmen kontinu mempunyai hubungan yang signifikan terhadap retensi. Penelitian lainnya dilakukan oleh Mehta et al. (2014) menemukan bahwa hubungan yang positif antara komitmen afektif dengan retensi, dimana besar komitmen afektif maka akan semakin tinggi retensi karyawan. Tung et al. (2014) dalam penelitiannya 
menunjukkan bahwa seluruh komponen (afektif, berkelanjutan, dan normatif) dari komitmen organisasional berhubungan positif dan signifikan dengan retensi karyawan.

Berdasarkan studi empiris sebelumnya, hipotesis yang dapat diajukan dalam penelitian ini adalah sebagai berikut.

$\mathrm{H}_{2}$ : Komitmen organisasional berpengaruh positif dan signifikan terhadap retensi karyawan.

Kartika (2011) penting bagi perusahaan untuk memberikan dukungan organisasi kepada karyawan guna mempertahankan karyawan, apabila seorang karyawan di dalam sebuah organisasi dapat merasakan adanya dukungan dari organisasi yang sesuai dengan norma, keinginan, harapan yang dimiliki karyawan, maka dengan sendirinya akan terbentuk sebuah komitmen dari karyawan untuk memenuhi kewajibannya kepada organisasi, dan tidak akan pernah meninggalkan organisasi. Retensi karyawan dapat berhasil karena adanya POS yang positif pada karyawan terhadap apa yang diberikan oleh organisasi sebagai penghargaan atas kontribusi yang diberikan para karyawan terhadap organisasi. POS yang positif diduga turut mempengaruhi keberhasilan retensi karyawan pada organisasi. Hasil penelitian yang dilakukan oleh Putra dan Agoes (2016) mengemukakan hasil bahwa perceived organizational support (POS) memiliki pengaruh yang positif dan signifikan terhadap retensi karyawan. Penelitian lain dilakukan Iqbal dan Maryam (2015) yang melakukan penelitian di Pakistan menemukan bahwa perceived organizational support (POS) berpengaruh positif dan signifikan terhadap retensi karyawan. Hasil yang sebanding dilakukan oleh Cahyana (2013) yang 
Ni Komang Astri Pramita Darmika, Pengaruh Pengembangan Karier...

mengemukakan bahwa perceived organizational support (POS) berpengaruh positif dan signifikan terhadap retensi karyawan.

Berdasarkan studi empiris sebelumnya, hipotesis yang dapat diajukan dalam penelitian ini adalah sebagai berikut.

$\mathrm{H}_{3}$ : Perceived organizational support (POS) berpengaruh positif dan signifikan terhadap retensi karyawan.

\section{METODE PENELITIAN}

Penelitian ini dilakukan pada The Lokha Ubud terletak di Banjar Bangkiang Sidem, Desa Keliki, Kecamatan Tegallalang, Kabupaten Gianyar. Lokasi ini dipilih karena ditemukan masalah-masalah terkait retensi karyawan, dimana diduga tingkat retensi karyawan dipengaruhi oleh pengembangan karier, komitmen organisasional, dan perceived organizational support. Objek penelitian ini adalah pengembangan karier (X1), komitmen organisasional (X2), dan perceived organizational support (X3) terhadap retensi karyawan (Y). Populasi penelitian ini adalah seluruh karyawan tetap di The Lokha Ubud yang berjumlah 88 orang. Perhitungan pengambilan sampel yang digunakan dalam penelitian ini adalah sampel jenuh dimana semua anggota populasi dilibatkan dalam penelitian ini yakni 88 orang.

Teknik analisis data yang digunakan dalam penelitian ini adalah analisis regresi linier berganda. Adapun model regresi linear berganda yang dapat dijabarkan dengan menggunakan persamaan sebagai berikut:

$$
\mathrm{Y}=\alpha+\beta 1 \mathrm{X} 1+\beta 2 \mathrm{X} 2+\beta 3 \mathrm{X} 3+\mathrm{e}
$$

\section{Keterangan:}

$\alpha \quad=$ Konstanta 
$\beta 1 \beta 2 \beta 3=$ Koefisien regresi

\begin{tabular}{|c|c|}
\hline Y & $=$ Retensi Karyawan \\
\hline $\mathrm{X} 1$ & $=$ Pengembangan Karier \\
\hline $\mathrm{X} 2$ & $=$ Komitmen Organisasional \\
\hline $\mathrm{X} 3$ & $=$ Perceived Organizational Support \\
\hline
\end{tabular}

Pengaruh variabel dependen terhadap variabel independen diuji dengan tingkat kepercayaan (Convidence interval) 95 persen atau $\alpha=5$ persen.

\section{HASIL DAN PEMBAHASAN}

Penelitian ini menggunakan sampel jenuh yang dimana seluruh populasi menjadi sampel, sehingga 88 karyawan yang diseleksi menjadi 85 sampel. Diseleksinya kembali sampel karena 3 kuesioner tidak terkumpul hal ini disebabkan karyawan yang tidak hadir karena sedang cuti hamil dan sakit sehingga 3 kuesioner tidak terkumpul.

Responden dalam penelitian ini sebagian besar berjenis kelamin laki-laki sebanyak 60 orang dengan persentase sebesar 70,59 persen. Sedangkan, untuk responden berjenis kelamin perempuan sebanyak 25 orang dengan persentase 29,41 persen. Artinya sebagian besar karyawan The Lokha Ubud mempekerjakan tenaga laki-laki. Hal ini menunjukkan sebagian besar karyawan yang diperlukan untuk bidangnya adalah tenaga kerja laki-laki karena The Lokha Ubud memiliki lokasi yang sangat luas sehingga karyawan harus memiliki tenaga yang lebih besar untuk menjangkau satu tempat ke tempat lainnya.

Responden berusia diantara 19-25 tahun dengan persentase sebesar 60,00 persen. Sedangkan untuk kelompok usia terendah yaitu 36-45 tahun dengan persentase sebesar 1,18 persen. Ini artinya The Lokha Ubud selalu melakukan 
Ni Komang Astri Pramita Darmika, Pengaruh Pengembangan Karier...

perekrutan karyawan baru, utamanya fresh graduate yang memiliki jiwa semangat tinggi untuk bekerja.

Responden berdasarkan pendidikan terakhirnya adalah SMA sebanyak 37 orang dengan persentase 43,53 persen. Sedangkan kelompok pendidikan terakhir paling kecil dimiliki oleh responden adalah D3 sebanyak 8 orang dengan persentase 9,41 persen. Ini artinya kebanyakan posisi karyawan cukup dengan tamat SMA yang diperhatikan ialah kecepatan dan ketepatan bekerja mereka di tempat kerja.

Responden berdasarkan masa kerja adalah yang memiliki masa kerja satu tahun sebanyak 20 orang dengan persentase 23,53 persen. Sedangkan yang memiliki masa kerja dua tahun sebanyak 30 orang dengan persentase sebesar 35,29 persen dan yang memiliki masa kerja tiga tahun sebanyak 35 orang dengan persentase sebesar 41,18 persen. Ini artinya The Lokha Ubud memiliki karyawan dengan masa kerja dominan 3 tahun karena terhitung mempertahankan karyawan lama yang berpengalaman.

Responden berdasarkan jabatan adalah waiter/ss sebanyak 11 orang dengan persentase sebesar 12,94 persen. Ini artinya posisi waiter/ss yang sangat dibutuhkan oleh The Lokha Ubud.

Metode regresi linier beranda digunakan dalam penelitian ini untuk mengetahui pengaruh Pengembangan Karier $\left(\mathrm{X}_{1}\right)$, Komitmen Organisasi $\left(\mathrm{X}_{2}\right)$, Perceived Organizational Support $\left(\mathrm{X}_{3}\right)$ dan Retensi (Y). Pengaruh variabel bebas terhadap variabel terikat diuji dengan tingkat kepercayaan 95 persen atau $\alpha=5$ persen. Metode ini diuji dengan menggunakan aplikasi SPSS 25.0 for windows diperoleh hasil analisis regresi linier berganda sebagai berikut. 
Tabel 2.

Hasil Analisis Regresi Linier Berganda

\begin{tabular}{|c|c|c|c|c|c|c|}
\hline \multicolumn{2}{|c|}{ Model } & \multicolumn{2}{|c|}{$\begin{array}{l}\text { Unstandardized } \\
\text { Coefficients }\end{array}$} & \multirow{2}{*}{$\begin{array}{c}\text { Standardized } \\
\text { Coefficients } \\
\text { Beta }\end{array}$} & \multirow[t]{2}{*}{$\mathbf{T}$} & \multirow[t]{2}{*}{ Sig. } \\
\hline & & B & $\begin{array}{l}\text { Std. } \\
\text { Error }\end{array}$ & & & \\
\hline \multirow[t]{6}{*}{1} & (Constant) & -2.766 & 1.209 & & -2.288 & 0,025 \\
\hline & Pengembangan Karier & 0,338 & 0,070 & 0,379 & 4.857 & 0,000 \\
\hline & Komitmen & 0,419 & 0,102 & 0,359 & 4.107 & 0,000 \\
\hline & Organisasional & & & & & \\
\hline & Perceived & 0,108 & 0,036 & 0,244 & 3.038 & 0,003 \\
\hline & Organizational Support & & & & & \\
\hline
\end{tabular}

Sumber : Data diolah, 2018

Berdasarkan hasil analisis regresi linier berganda pada Tabel 3, maka persamaan regresinya adalah sebagai berikut.

$$
Y=-2,776+0,338 X_{1}+0,419 X_{2}+0,108 X_{3}
$$

Nilai koefisien regresi pengembangan karier $\left(\mathrm{X}_{1}\right)$ sebesar 0,338 dapat dinyatakan berarti bahwa ada pengaruh positif antara pengembangan karier dengan retensi karyawan yang berarti apabila pengembangan karier meningkat maka retensi karyawan juga akan meningkat, begitu pula sebaliknya.

Nilai koefisien regresi komitmen organisasional $\left(\mathrm{X}_{2}\right)$ sebesar 0,419 dapat dinyatakan berarti bahwa ada pengaruh positif antara komitmen organisasional dengan retensi karyawan yang berarti apabila komitmen organisasional meningkat maka retensi karyawan juga akan meningkat, begitu pula sebaliknya.

Nilai koefisien regresi perceived organizational support $\left(\mathrm{X}_{3}\right)$ sebesar 0,108 dapat dinyatakan berarti bahwa ada pengaruh positif antara perceived organizational support dengan retensi karyawan yang berarti apabila perceived organizational support meningkat maka retensi karyawan juga akan meningkat, begitu pula sebaliknya. 
Tabel 3.

Hasil Uji Kelayakan Model (Uji F)

\begin{tabular}{|c|c|c|c|c|c|c|}
\hline \multicolumn{2}{|c|}{ Model } & $\begin{array}{l}\text { Sum of } \\
\text { Squares }\end{array}$ & Df & $\begin{array}{l}\text { Mean } \\
\text { Square }\end{array}$ & $\mathbf{F}$ & Sig. \\
\hline \multirow[t]{3}{*}{1} & Regression & 248.447 & 3 & 82.816 & 55.508 & $.000^{\mathrm{b}}$ \\
\hline & Residual & 120.848 & 81 & 1.492 & & \\
\hline & Total & 369.294 & 84 & & & \\
\hline
\end{tabular}

Sumber: Data diolah, 2018

Pada Tabel 4 Hasil Uji F dapat dilihat nilai signifikan yakni 0,000 kurang dari $0,05(0,000<0,05)$ sehingga $\mathrm{H}_{0}$ ditolak. Dengan kata lain Pengembangan Karier, Komitmen Organisasional, dan Perceived Organizational Support berpengaruh positif dan signifikan terhadap variabel terikatnya yaitu Retensi Karyawan.

Tabel 4.

Hasil Analisis Koefisien Determinasi $\left(\mathbf{R}^{2}\right)$

\begin{tabular}{lcccc}
\hline Model & R & R Square & $\begin{array}{c}\text { Adjusted R } \\
\text { Square }\end{array}$ & $\begin{array}{c}\text { Std. Error of the } \\
\text { Estimate }\end{array}$ \\
\hline 1 & $.820^{\mathrm{a}}$ & .673 & .661 & 1.221 \\
\hline Sumber : Data diolah, 2018 & & & &
\end{tabular}

Berdasarkan Tabel 4 dapat dilihat nilai $R$ Square sebesar 0,673 sehingga dapat dihitung persentase kontribusi Pengembangan Karier, Komitmen Organisasi dan Perceived Organizational Support terhadap Retensi sebesar 0,673 x 100\% $=67,3$ persen dengan sisa 32,7\% dipengaruhi olehvariabel lain diluar penelitian ini.

\begin{tabular}{|c|c|c|c|c|c|c|}
\hline \multicolumn{7}{|c|}{$\begin{array}{l}\text { Tabel } 5 . \\
\text { Hasil Uii t }\end{array}$} \\
\hline & \multirow[b]{2}{*}{ Model } & \multicolumn{2}{|c|}{$\begin{array}{c}\text { Coefficients }^{\mathbf{a}} \\
\text { Unstandardized } \\
\text { Coefficients }\end{array}$} & \multirow{2}{*}{$\begin{array}{c}\text { Standardized } \\
\text { Coefficients } \\
\text { Beta }\end{array}$} & \multirow[b]{2}{*}{$\mathbf{T}$} & \multirow[b]{2}{*}{ Sig. } \\
\hline & & B & $\begin{array}{l}\text { Std. } \\
\text { Error }\end{array}$ & & & \\
\hline \multirow[t]{5}{*}{1} & (Constant) & -2.766 & 1.209 & & -2.288 & 0.025 \\
\hline & Pengembangan Karier & 0.338 & 0.070 & 0.379 & 4.857 & 0.000 \\
\hline & Komitmen & 0.419 & 0.102 & 0.359 & 4.107 & 0.000 \\
\hline & Organisasional & & & & & \\
\hline & $\begin{array}{l}\text { Perceived Organizational } \\
\text { Support }\end{array}$ & 0.108 & 0.036 & 0.244 & 3.038 & 0.003 \\
\hline
\end{tabular}

Sumber : Data diolah, 2018

Pada Tabel 5 hasil uji t, diketahui bahwa variabel pengembangan karier memiliki nilai koefisien beta positif sebesar 0,338 dengan nilai Sig. sebesar 0,000. 
Nilai Sig. 0,000 $<0,05$ mengindikasikan bahwa $\mathrm{H}_{1}$ diterima. Dengan kata lain pengembangan karier berpengaruh positif dan signifikan terhadap retensi.

Pada Tabel 5 hasil uji t, diketahui bahwa variabel komitmen organisasional memiliki nilai koefisien beta positif sebesar 0,419 dengan nilai Sig. sebesar 0,000. Nilai Sig. 0,000 $<0,05$ mengindikasikan bahwa $\mathrm{H}_{2}$ diterima. Dengan kata lain komitmen organisasional berpengaruh positif dan signifikan terhadap retensi.

Pada Tabel 5 hasil uji t, diketahui bahwa variabel perceived organizational support memiliki nilai koefisien beta positif sebesar 0,108 dengan nilai Sig. sebesar 0,003. Nilai Sig. 0,003 $<0,05$ mengindikasikan bahwa $\mathrm{H}_{3}$ diterima. Dengan kata lain perceived organizational support berpengaruh positif dan signifikan terhadap retensi.

Pengujian hipotesis pada pengaruh pengembangan karier terhadap retensi karyawan menunjukkan bahwa pengembangan karier berpengaruh positif dan signifikan terhadap retensi karyawan. Artinya semakin baik pengembangan kair di dalam perusahaan maka retensi yang dimiliki karyawan The Lokha Ubud akan meningkat dan sebaliknya.

Hipotesis satu $\left(\mathrm{H}_{1}\right)$ dalam penelitian ini menyatakan bahwa pengembangan karier berpengaruh positif dan signifikan terhadap retensi karyawan. Berdasarkan hasil distribusi jawaban responden variabel pengembangan karier diketahui bahwa pengembangan karier memiliki pengaruh yang signifikan. Hasil yang signifikan ini disebabkan oleh indikator bahwa karyawan merasa adil atas kesempatan naik jabatan yang diberikan perusahaan sehingga karyawan berminat untuk mengembangkan karier saya di dalam perusahaan. Sehingga dapat disimpulkan 
Ni Komang Astri Pramita Darmika, Pengaruh Pengembangan Karier...

bahwa hasil ini menerima $\mathrm{H}_{1}$ yakni pengembangan karier berpengaruh positif dan signifikan terhadap retensi.

Hasil penelitian ini sesuai dengan penelitian yang dilakukan oleh Kwenin (2013), Ramadhani dan Engkos (2013), Poerbaningtyas (2015), Sitati et al. (2016), Pratiwi dan Sriathi (2017) menyatakan bahwa pengembangan karier berpengaruh positif dan signifikan terhadap retensi karyawan. Kroon and Freese (2013) menemukan bahwa peluang pengembangan karier dapat secara positif meningkatkan komitmen karyawan untuk tinggal di organisasi. Penelitian Khan (2014) menemukan bahwa pengembangan karier meningkatkan retensi karyawan terhadap perusahaan pada sektor perbankan di Pakistan.

Pengujian hipotesis pada pengaruh komitmen organisasional terhadap retensi karyawan menunjukan bahwa komitmen organisasional berpengaruh positif dan signifikan terhadap retensi. Artinya semakin tinggi komitmen karyawan pada organisasi maka retensi yang dimiliki karyawan The Lokha Ubud akan meningkat.

Hipotesis dua $\left(\mathrm{H}_{2}\right)$ dalam penelitian ini menyatakan bahwa komitmen oganisasional berpengaruh positif dan signifikan terhadap retensi karyawan. Berdasarkan hasil distribusi jawaban responden variabel komitmen organisasional diketahui bahwa komitmen organisasional memiliki pengaruh yang signifikan. Hasil yang signifikan ini disebabkan oleh indikator karyawan memiliki rasa bahwa harus berada di perusahaan untuk mencapai visi misi perusahaan. Sehingga dapat disimpulkan bahwa hasil ini menerima $\mathrm{H}_{2}$ yakni komitmen organisasional berpengaruh positif dan signifikan terhadap retensi karyawan. 
Hasil penelitian ini sesuai dengan penelitian yang dilakukan oleh Tung et al. (2014), Fukuoka (2014), Nguyen (2014), Ula dan Wahibur (2016), Rose and Raja (2016) menyatakan bahwa komitmen organisasional berpengaruh positif dan signifikan terhadap retensi karyawan. Shanker (2013) di perusahaan india menunjukan bahwa dua dari jenis komitmen organisasional yaitu komitmen afektif dan komitmen kontinu mempunyai hubungan yang signifikan terhadap retensi karyawan. Mehta et al. (2014) dalam studi tentang retensi dan komitmen karyawan menemukan bahwa hubungan yang positif antara komitmen afektif dengan retensi, dimana besar komitmen afektif maka akan semakin tinggi retensi karyawan.

Pengujian hipotesis pada pengaruh perceived organizational support terhadap retensi karyawan menunjukan bahwa perceived organizational support berpengaruh positif dan signifikan terhadap retensi. Artinya semakin tinggi perceived organizational support yang diberikan organisasi dan dirasakan oleh karyawan maka retensi yang dimiliki karyawan The Lokha Ubud akan meningkat.

Hipotesis tiga $\left(\mathrm{H}_{3}\right)$ dalam penelitian ini menyatakan bahwa perceived organizational supoort berpengaruh positif dan signifikan terhadap retensi karyawan. Berdasarkan hasil distribusi jawaban responden variabel perceived organizational support diketahui bahwa perceived organizational support memiliki pengaruh yang signifikan. Hasil yang signifikan ini disebabkan oleh indikator bahwa karyawan merasa perusahaan peduli tentang kesejahteraannya. Sehingga dapat disimpulkan bahwa hasil ini menerima $\mathrm{H}_{3}$ yakni perceived organizational support berpengaruh positif dan signifikan terhadap retensi karyawan. 
Ni Komang Astri Pramita Darmika, Pengaruh Pengembangan Karier...

Hasil penelitian ini sesuai dengan penelitian yang dilakukan oleh Cahyana (2013), Iqbal dan Maryam (2015), Wijayanti dan Harlina (2015), Putra dan Agoes (2016) menyatakan bahwa perceived organizational support berpengaruh positif terhadap retensi karyawan. Kartika (2011) pada hotel berbintang lima di Surabaya menyatakan bahwa penting bagi organisasi meningkatkan dukungan organisasi pada karyawan guna mempertahankan karyawan.

Faktor yang berhubungan dengan retensi karyawan dalam penelitian ini adalah pengembangan karier, komitmen organisasional dan perceived organizational support. Implikasi teoritis yang berkaitan dengan retensi secara konsisten memperkuat teori sebelumnya bahwa pengembangan karier, komitmen organisasional dan perceived organizational support mempengaruhi retensi karyawan. Dalam penelitian ini menyatakan bahwa pengembangan karier memiliki pengaruh positif dan signifikan terhadap retensi karyawan, hal ini menunjukkan bahwa semakin perusahaan memberikan kesempatan kepada karyawan dalam mengembangkan kariernya melalui program - program yang diberikan The Lokha Ubud seperti pelatihan maka akan semakin besar pengaruhnya pada karyawan untuk tetap bertahan pada perusahaan.

Hasil penelitian berikutnya menyatakan bahwa komitmen organisasional berpengaruh positif dan signifikan terhadap retensi karyawan, hal ini berarti semakin terbentuknya rasa komitmen organisasional pada karyawan maka akan semakin kuat keinginan karyawan untuk tetap berada pada perusahaan untuk itu perusahaan harus tetap menjaga komitmen karyawan pada organisasi sehingga retensi karyawan tetap terjaga bahkan meningkat. 
Hasil penelitian yang terakhir menyatakan bahwa perceived organizational support berpengaruh positif dan signifikan terhadap retensi karyawan, hal ini menunjukan bahwa semakin perusahaan menghargai kontribusi serta peduli dengan kesejahteraan karyawan maka akan semakin besar pengaruhnya kepada karyawan untuk tetap semangat dalam bekerja dan menjadi motivasi karyawan untuk tetap berada pada perusahaan sehingga retensi karyawan dapat dipertahankan.

Hal ini mendukung penelitian yang telah diungkapkan pada hipotesis penelitian, sehingga dapat disimpulkan bahwa penelitian ini mendukung serta memperjelas hubungan antara variabel pengembangan karier, komitmen organisasional, perceived organizational support, dan retensi.

Penelitian ini diharapkan akan memberikan kontribusi positif bagi semua pihak khususnya karyawan dan perusahaan. Bagi karyawan hendaknya ikut ambil bagian dan memiliki loyalitas tinggi untuk tetap menjaga dan meningkatkan retensi, karena merupakan suatu kepuasan tersendiri bagi karyawan jika mampu mempertahankan dirinya dan menunjukkan bahwa semakin tinggi dan meningkatnya retensi karyawan dalam perusahaan maka semakin tinggi kualitas kerja perusahaan. Bagi pihak The Lokha Ubud dalam menjaga dan meningkatkan retensi karyawan sebaiknya memperhatikan pengembangan karier, komitmen organisasional dan perceived organizational support karyawan agar dapat berjalan dengan baik dan sesuai yang telah ditetapkan oleh perusahaan, hal ini penting karena aspek tersebut dapat mempengaruhi produktivitas dan kinerja The Lokha Ubud. 
Ni Komang Astri Pramita Darmika, Pengaruh Pengembangan Karier...

Terdapat keterbatasan yang mempengaruhi kondisi dari penelitian yang dilakukan. Adapun keterbatasan dalam penelitian ini yaitu: jumlah responden hanya 88 orang karyawan dan hanya dari lingkungan The Lokha Ubud, sehingga hasil penelitian ini hanya dapat diterapkan dilingkungan kerja The Lokha Ubud dan tidak dapat digeneralisasi pada lingkungan perusahaan lain. Terkumpulnya kembali kuesioner hanya 85 kuesioner dikarenakan 3 kuesioner lainnya tidak terkumpul akibat tidak hadirnya karyawan. Faktor-faktor yang mempengaruhi retensi karyawan dalam penelitian ini hanya terdiri dari tiga variabel, yaitu pengembangan karier, komitmen organisasional dan perceived organizational support, sedangkan masih banyak faktor lain yang mempengaruhi retensi karyawan.

\section{SIMPULAN DAN SARAN}

Pengembangan karier berpengaruh positif dan signifikan terhadap Retensi karyawan. Hal ini menunjukan semakin meningkat pengembangan karier di dalam perusahaan maka retensi karyawan semakin meningkat pula. Komitmen organisasional berpengaruh positif dan signifikan terhadap Retensi karyawan. Hal ini berarti semakin kuatnya komitmen organisasional yang dimiliki karyawan dalam organisasinya, maka semakin tinggi tingkat retensi karyawan. Perceived organizational support berpengaruh positif dan signifikan terhadap Retensi karyawan. Hal ini menunjukan bahwa semakin tinggi rasa karyawan bahwa perusahaan peduli akan kesejahteraan karyawan maka keinginan bertahan di dalam perusahaan semakin meningkat. 
Saran secara teoritis yang dapat diberikan dari penelitian ini adalah perusahaan harus memperhatikan pengembangan karier, komitmen organisasional, dan perceived organizational support dalam perusahaan untuk meningkatkan retensi karyawan. Perusahaan diharapkan perlu memperhatikan hubungan karyawan dengan atasan dalam kaitannya dengan pengembangan karier serta karyawan mendapatkan informasi yang lengkap mengenai syarat dalam menduduki suatu jabatan. Hal ini dilakukan agar karyawan merasa puas terhadap jenjang karier yang disediakan sudah sesuai dengan bidang masingmasing. Perusahaan diharapkan lebih melibatkan karyawan dalam pemecahan permasalahan yang ada di perusahaan. Hal ini dilakukan agar karyawan memiliki rasa memiliki terhadap perusahaan sehingga karyawan merasa khawatir jika harus meninggalkan perusahaan. Perusahaan diharapkan perlu lebih menghargai kontribusi dan usaha ekstra yang telah dilakukan karyawan serta keluhan yang dirasakan karyawan. Perusahaan juga lebih terbuka bila karyawan lalai dalam menjalankan tanggung jawab agar memberikan teguran. Sehingga karyawan merasa bahwa perusahaan memiliki perhatian kepada karyawan serta perusahaan peduli dan bangga atas kinerja karyawan.

Penelitian selanjutnya diharapkan untuk mengkaji lebih banyak sumber maupun referensi yang terkait dengan variabel penelitian, serta mempertimbangkan variabel-variabel lain yang mempengaruhi retensi karyawan seperti lingkungan kerja, iklim organisasi, kompensasi dan lain sebagainya serta peneliti disarankan agar lebih memperluas industri penelitian seperti hospitality, manufaktur, umkm, dan lain sebagainya, dan disarankan kepada peneliti 
selanjutnya untuk menggunakan metode uji yang baru agar memperoleh hasil maksimal seperti dengan metode ntervening atau moderasi.

\section{REFERENSI}

Aditeresna, Kadek Arya Reta., dan Ni Wayan Mujiati. (2018). Pengaruh Kompensasi, Kepuasan Kerja dan Pengembangan Karier Terhadap Retensi Karyawan di Kuta Bex Hotel. E-Jurnal Manajemen Unud, 7 (11), 58145845.

Benlioglu, B. (2014). The Examination of The Effect of Perceived Organizational Support of University Teaching Staff on Organisational Commitment. Mevlana International Journal of Education (MIJE). 4(2), 37-51.

Cahyana, B. (2013). Analisis Pengaruh Perceived Organizational Support Dan Organizational Trust Terhadap Kepuasan Karyawan Dan Dampaknya Terhadap Retensi Karyawan Pada Pt. Lestarindo Perkasa. Binus University e-Thesis Repository.

Candra, Ni Nyoman Witya. (2016). Pengaruh Pengalaman Kerja, Pendidikan Dan Pelatihan Terhadap Pengembangan Karier Di PT. PLN (Persero) Distribusi Bali. E-Jurnal Manajemen Unud, 5(9), 5839-5867.

Crow, M. S., Chang-Bae, L., Jae-Jin, J. (2012). Organizational Justice and Organizational Commitment Among South Korean Police Officers: An Investigation of Job Statisfaction as a Mediator. Policing: An International Journal of Police Strategies dan Management. 35 (2), 402-423.

Dessler, Gary. (2009). Manajemen Sumber Daya Manusia. Edisi Kesepuluh Jilid 2. Jakarta: PT Macanan Jaya Cemerlang.

Fahrizal., dan I Wayan Mudiartha Utama. (2017). Pengaruh Persepsi Dukungan Organisasi Terhadap Komitmen Organisasional Dan Turnover Intention Karyawan Hotel Kajane Mua Ubud. E-Jurnal Manajemen Unud, 6 (10), 5405-5431.

Farasat, E. (2013). Perceived Organizational Support and Deviant Behavior. Journal of Basic and Applied Scientific Research. 3(5), 517-528.

Gillies, DA. (1989). Manajemen Keperawatan: Suatu Pendekatan Sistem. Edisi kedua. Terjemahan Illion: WB Saunders Company.

Grace. (2013). Hubungan antara Perceived Organizational Support dengan Work Engagement Pada Guru SMA Swasta di Surabaya. Jurnal Psikologi Industri dan Organisasi. 2(2), 90-99.

Griffin, Ricky W. (2004). Manajemen. Edisi 7. Jilid 1. Jakarta: Erlangga. 
Hafanti, O., dan Rahman, L., dan Hafasnudi. (2015). Pengaruh Kompensasi, lingkungan kerja, dan Desain Tugas Terhadap Kepuasan Kerja dan Dampaknya Terhadap Retensi Karyawan Palang Merah Indonesia (PMI) Provinsi Aceh. Jurnal Manajemen Pasca Universirtas Syiah Kuala, 4 (1), 164-173.

Haryani, Putu Yeni. (2013). Korelasi Antara Pengembangan Karier Dengan Motivasi Kerja Dan Keinginan Untuk Pensiun Dini. Jurnal Buletin Study Ekonomi. 2(6), 116-120.

Iqbal, S., and Maryam, S. H. (2015). "Impact of Perceived Organizational Support on Employee Retention with Mediating Role of Psychological Empowerment". Pakistan Journal of Commerce and Social Sciences, 9(1), 18-34.

Jennifer A, Carsen. (2005). HR How To Employee Retention. Chicago : J.D. CCH Incorporated.

Khan, R. A. (2014). The Impact of Career Planing and Development On Job Satisfaction and Retention in Pakistan Banking Sector. Global Management Journal of Academic and Corporate Studies. 4(2), 109-116

Kroon, B. and Freese, C. (2013). Can HR Practices Retain Flexworkers with Their Agency? International Journal of Manpower. 34(8), 899-917.

Kwenin, D. O. (2013). Relationship Between Work Environment, Career Development Opportunities And Employee Retention In Vodafane Ghana Limited. Journal Of Human Resource Management, 1 (4), 1-9

Lamba, S., and Nirmala, C. (2013). Impact of HRM Practices on Organizational Commitment of Employees. International Journal of Advancements in Research dan Technology, 2(4), 407-423.

Luthans, Fred (2008). Organizational Behavior. United States:McGraw-Hill

Malik, F., Chugtai, S., Iqbal, Z., Ramzan, M. (2013). Does Psychological Empowerment Bring about Employee Commitment? Evidence from Telecomunication Sector of Pakistan. Journal of Business Studies Quarterly, 5(1), 14-21

Mathis Robert L., and Jackson John H. (2011). Human Resource Management, Edisi Sepuluh. Jakarta: Salemba Empat.

Mehta, M., and Aarti, K. (2014). Study on Employee Retention and Commitment. International Journal of Advance Research in Computer Science and Management Studies. 2(2), 154-164.

Mustika, I. K. (2012). Analisis Budaya Organisasi dan Kepuasan Kerja Melalui Komitmen Pengaruhnya Terhadap Intent to Leave Karyawan pada Industri 
Jasa Perhotelan di Kabupaten Badung dan Kota Denpasar. Jurnal Mitra Ekonomi dan Manajemen Bisnis. 3 (1), 1-24.

Nguyen, P., Felfe, J., and Fooken, I. (2014). "Work Conditions as Moderators of the Relationship Between Western Expatriates Commitment and Retention in Internasional Assignments". Evidance-Based HRM: A Global Forum for Empirical Scholaship, 2(2), 145-163.

Parerung, A., Adolfina Peggy, A. Mekel. (2014). Disiplin, Kompensasi dan Pengembangan Karier Pengaruhnya terhadap Kinerja Pegawai pada Badan Lingkungan Hidup Provinsi Sulawesi Utara. Jurnal EMBA 2(4), 688-696

Permata, P. R., dan Rahardja. (2016). Analisis Pengaruh Sistem Reward, Motivasi Kerja, dan Komitmen Organisasional Terhadap Retensi Karyawan (Studi Pada Karyawan PT Primayudha Mandirijaya. Dipenegoro Journal of Management. 5 (3), 1-11.

Poerbaningtyas, L. S. (2015). Analisis Pengaruh Pengembangan Karier dan Kinerja Karyawan Terhadap Retensi Karyawan Pada Divisi Produks PT Net Mediatama Indonesia. Binus University e-Thesis Repository.

Pratiwi, Luh Putu Yunia Anggy., dan Anak Agung Ayu Sriathi. (2017). Pengaruh Lingkungan Kerja dan Pengembangan Karier Terhadap Retensi Karyawan Pada Hotel Santika Nusa Dua Bali. E-Jurnal Manajemen Unud, 6 (3), 14781506

Putra, IB Gd Swambawa., dan Agoes Ganesha Rahyuda. (2016). Pengaruh Kompensasi, Lingkungan Kerja Dan Perceived Organizational Support (POS) Terhadap Retensi Karyawan. E-Jurnal Manajemen Unud, 5 (2), 810837.

Putra, I Putu Agus Praditya Adi., dan I Wayan Mudiartha Utama. (2018). Pengaruh Budaya Organisasi, Komitmen Organisasional dan Kompensasi Terhadap Retensi Karyawan. E-Jurnal Manajemen Unud, 7 (11), 2302-8912.

Ragupathi. (2013). The Employee Retention Practices of MNC'S in Hyderabad. Research Journal of Management Sciences. 2 (4), 21-24.

Rahmawati, N.P., B. Swasto, dan A. Prasetya. (2014). Pengaruh lingkungan kerja terhadap kinerja karyawan (Studi pada karyawan Kantor Pelayanan Pajak Pratama Malang Utara). Jurnal Administrasi Bisnis, 8(2), 1-9.

Ramadhani, N. A., dan Kuncoro. (2013). Analisis Pengaruh Pengembangan Karier, Dukungan Supervisor, Lingkungan Kerja, dan Penghargaan Terhadap Retensi Karyawan Pada PT. Agranet Multicitra Siberkom (Detikcom) Divisi Redaksi Jakarta. Binus University e-Thesis Repository.

Rhoades, L. and R. Eisenberger. (2002). "Perceived organizational support: a review of the literature." Journal of Applied Psychology, 87(4), 698-714. 
Robbins, Stephen P dan Timothy A. Judge. (2015). Perilaku Organisasi Edisi 16 terjemahan. Jakarta: Salemba Empat

Robbins dan Coulter, Mary. (2009). Manajemen Jilid 1 dan 2 Edisi Kedelapan. Jakarta PT Indeks.

Rose, Swapna and Raja, K. G. (2016). Role of HR Practices, Job Satisfaction, and Organization Commitment in Employee Retention. CLEAR International Journal of Research in Commerce and Management. 7(10), 1-3.

Samuel, Michael O., and Crispen Chipunza. (2009). Employee retention and turnover: Using motivational variables as a panacea. African Journal of Business Management. 3 (8), 410-415.

Sari, E., dan Joni Sinulingga. (2011). Pengaruh Pengembangan Karier Dan Kompensasi Terhadap Motivasi Karyawan. Jurnal Ilmiah Penelitian Manajemen Manajerial. 2(1), 431-440.

Shanker, Meera. (2013). Organizational Commitment and Employees' Intention to Stay in Indian Companies : Factor Analytical Approach. Journal of Psychosocial Research. 8 (2), 199-208.

Siagian, S. P. (2012). Manajemen Sumber Daya Manusia. Jakarta: Bumi Aksara Indonesia.

Sumarni, Murti. (2011). Pengaruh Employe Retention Terhadap Turnover Intention dan Kinerja Karyawan. Juernal Akuntansi dan Manajemen. Vol 8, 20-47.

Syarafuddin Alwi. (2008). Manajemen Sumber Daya Manusia Strategi Keunggulan Kompetitif, BPFE, Yogyakarta

Tung N. Nguyen, Khuong N. Mai, and Phuong V. Nguyen. (2014). "Factors Affecting Employees' Organizational Commitment-A Study of Banking Staff in Ho Chi Minh City, Vietnam. Journal of Advanced Management Science. 2(1), 7-11.

Vroom, Victor. H. (1964). Work and Motivation. New York: John Willey dan Son.

Wahyuni, D. U, Hamidah, N., dan Ruhana, I. (2014). Pengaruh Pengembangan Karier Terhadap Prestasi Kerja Karyawan Studi pada Karyawan Tetap PT. Astra Internasional, Tbk Daihatsu Malang. Jurnal Administrasi Bisnis (JAB), 8(1), 1-10.

Wijayanti, C. W., dan Nurtjahjanti. (2015). Perceived Organizational Support dan Retensi Pada Karyawan PKWT Proyek Dermaga Petikemas PT. PP (PERSERO) Jakarta. E-Jurnal Empati, 4 (1), 49-54.

Wu Wann. (2011). The Impacts Of Perceived Organizational Support, Job Satisfaction, And Organizational Commitment On Job Performance In 
Ni Komang Astri Pramita Darmika, Pengaruh Pengembangan Karier...

Hotel Industry. The 11th International DSI and the 16th APDSI Joint Meeting. 12-19. 